\title{
ВПЛИВ ЦИФРОВОЇ ЕКОНОМІКИ \\ ТА ЄВРОПЕЙСЬКОЇ ІНТЕГРАЦІЇ НА ПРАВОТВОРЧІСТЬ \\ У СФЕРІ ІНТЕЛЕКТУАЛЬНОЇ ВЛАСНОСТІ В УМОВАХ \\ РОЗБУДОВИ ІНФОРМАЦІЙНОГО СУСПІЛЬСТВА \\ ТА ІНФОРМАЦЙНОГО ЗАКОНОДАВСТВА В УКРАЇНІ
}

\author{
Арістова I. В., Карпик Ю. А.
}

\section{ВСТУП}

Загальновизнано, що майбутнє світу та й України загалом грунтується на цифрових технологіях, поштовх яким дає, серед іншого, й сучасна цифрова економіка. Актуальність цього феномена зазначено й на міжнародному рівні, коли питання цифрової економіки вперше було внесено в порядок денний групи G20 на саміті в Анталії у 2015 р. та визнано, що ми живемо в епоху економіки Інтернету르. Варто підкреслити, що Україна забезпечує поступове приведення своїх чинних законів чи прийняття нових законів у відповідність до європейського законодавства за трьома основними напрямами: інтероперабельність (Interoperability) та електронні сервіси (eServices); індустрія відкритих даних; електронна ідентифікація (eID). Тому не випадково, що в Концепції розвитку цифрової економіки та суспільства України на 2018-2020 рр. акцентовано увагу на тому, що «важливими для розвитку цифрової економіки є м'які цифрові інфраструктури, які не повинні залишатися поза увагою, зокрема й інфраструктура блокчейн»².

Однією з рушійних сил розвитку цивілізації $є$ творча інтелектуальна діяльність. Країни з ринковою економікою давно усвідомили значення використання й належної охорони результатів творчої діяльності, об’єднуваних у понятті «інтелектуальна власність», для темпів соціального та економічного розвитку ${ }^{3}$. Важливість розв'язання цього завдання закріплено в Угоді про асоціацію України з Європейським

\footnotetext{
1 G20 Программа по развитию и сотрудничеству в сфере цифровой экономики (Итоговый документ - 2016). URL: http://www.eurasiancommission.org/ru/act/dmi/workgroup/ materials/ (дата звернення: 12.02.2020).

2 Про схвалення Концепції розвитку цифрової економіки та суспільства України на 2018-2020 роки та затвердження плану заходів щодо її реалізації : Розпорядження Кабінету Міністрів від 17.01.2018 № 67-p. URL: https:/www.kmu.gov.ua/npas/pro-shvalennyakoncepciyi-rozvitku-cifrovoyi-ekonomiki-ta-suspilstva-ukrayini-na-20182020-roki-tazatverdzhennya-planu-zahodiv-shodo-yiyi-realizaciyi (дата звернення: 12.02.2020).
}

3 Яновицька Г.Б., Кучер В.О. Цивільне право України : підручник : у 2 т. / за ред. Г.Б. Яновицької, В.О. Кучера. Львів : Новий Світ-2000, 2014. С. 384. 
Союзом (далі - $\mathrm{CC})^{4}$. Варто усвідомлювати, що Україна, отже, у короткий проміжок часу повинна пройти шлях держав-членів $С С$ у питанні запровадження високих стандартів охорони прав інтелектуальної власності в умовах інформаційного суспільства та цифрової економіки.

У роботі відстоюється позиція, що цифрова економіка постає однією з ознак інформаційного суспільства, яке у своєму розвитку проходить декілька етапів ${ }^{5}$. Якщо виходити 3 того, що перший етап розвитку інформаційного суспільства переважним чином грунтується на досягненнях інформаційних технологій і технологій зв'язку, то наступний етап його розбудови має припускати більш широкі соціальні, етичні та політичні параметри - це нове суспільство знань. Водночас використання інформаційно-комунікаційних технологій (далі - IКТ) для створення суспільств знань у різних країнах світу має бути спрямоване на розвиток людства на основі передусім прав людини. Безумовно, у нових умовах виникає об'єктивна потреба в переосмисленні ролі права, напрямів розвитку галузей права та їх взаємодії. Варто підтримати точку зору стосовно важливої ролі права у свідомому проектуванні інформаційних процесів: за допомогою права не лише регулюються відносини, що виникають у суспільстві, а й відбувається розширення сфери інформаційної діяльності, що зумовлено суспільними потребами ${ }^{6}$.

Важливо, що державна підтримка зазначеної позиції втілена, наприклад, у Рекомендації парламентських слухань на тему: «Законодавче забезпечення розвитку інформаційного суспільства в Україні» (далі Рекомендації) 7 . Ураховуючи низку наявних проблем в інформаційній сфері, зокрема необхідність розвитку інформаційного законодавства, проведення системної кореляції з вирішення питань захисту й забезпечення основних прав, цінностей і соціально-економічних інтересів людини, суспільства й держави, а також з метою забезпечення розвитку інформаційного суспільства в Україні, у документі закріплено

\footnotetext{
4 Угода про асоціацію між Україною, з однісї сторони, та Європейським Союзом, Європейським співтовариством 3 атомної енергії і їхніми державами-членами, 3 іншої сторони, ратифікована із заявою Законом України від 16.09.2014 № 1678-VII. URL: https://zakon.rada.gov.ua/laws/show/984_011 (дата звернення: 12.02.2020).

5 Арістова І.В. Наука «Інформаційне право» на новому етапі розвитку інформаційного суспільства. Правова інформатика. 2011. № 1. С. 3.

6 Арістова І.В. Наука «Інформаційне право» на новому етапі розвитку інформаційного суспільства. Правова інформатика. 2011. № 1. С. 4.

7 Про Рекомендації парламентських слухань на тему: «Законодавче забезпечення розвитку інформаційного суспільства в Україні»: Постанова Верховної Ради України від 03.07.2017 № 1565-VII. Відомості Верховної Ради Украӥни. 2014. № 33. Ст. 1163.
} 
відповідні рекомендації8. Наприклад, з метою розвитку електронної економіки Кабінету Міністрів України (далі - КМУ) пропонувалося, серед іншого, активізувати розроблення та впровадження новітніх IКТ, унести законодавчі пропозиції щодо вдосконалення оцінювання об' єктів інтелектуальної власності в Україні задля правового захисту зазначених активів. Усвідомлення важливості наукового й науково-технічного забезпечення розвитку інформаційного суспільства зумовило постановку завдань щодо: 1) організації та забезпечення розроблення наукових і прикладних засад трансформації інформаційного суспільства в суспільство знань як інноваційну основу подальшого суспільно-економічного розвитку України; 2) забезпечення з урахуванням рішень Національної академії правових наук України, виокремлення інформаційного права та права інтелектуальної власності в окрему наукову спеціальність розвитку інформаційного суспільства 9 .

Отже, тема статті належить до пріоритетних наукових досліджень щодо розвитку інформаційного суспільства як із соціогуманітарних, так і технологічних та інноваційних проблем.

\section{1. Методологія дослідження. Понятійний апарат: правові засоби, інструменти цифрової економіки}

Уважаємо за необхідне зазначити, що в статті відстоюється різноманітна ідея суспільства знань - «Сдність у різноманітті», яка проголошена міжнародною організацією ЮНЕСКО ${ }^{10}$. Грунтуючись на зазначеній ідеї, пропонуємо розкрити предмет дослідження шляхом використання об'єднаних знань як різноманітних галузевих юридичних наук, так й інформаційних (технічних наук). Варто підкреслити, що взаємодія виникає там і тоді, де зв'язок між науками об'єднаний спільною метою. Отже, зазначений підхід зумовлений необхідністю досягнення спільної мети - розбудови глобального інформаційного суспільства, заснованого на цифрових технологіях, знанні та забезпеченні передусім прав людини. Водночас варто підкреслити, що на важливість проведення міждисциплінарних досліджень в умовах розбудови інформаційного суспільства, а отже, інформаційної економіки свого часу звертали увагу юристи - фахівці в галузі інформаційного

\footnotetext{
8 Про Рекомендації парламентських слухань на тему: «Законодавче забезпечення розвитку інформаційного суспільства в Україні»: Постанова Верховної Ради України від 03.07.2017 № 1565-VII. Відомості Верховної Ради Украӥни. 2014. № 33. Ст. 1163.

9 Там само.

10 К обществам знаний : Всемирный доклад ЮНЕСКО. Париж : Изд-во ЮНЕСКО, 2005. $211 \mathrm{c}$.
} 
права (зокрема I.В. Арістова ${ }^{11}$, К.І. Бєляков ${ }^{12}$ ) Сьогодні до цього вже закликають і фахівці в галузі інформаційних технологій ${ }^{13}$. Отже, існує об'єктивна потреба в активізації досліджень, що мають міждисциплінарний характер.

Мета статті - визначення особливостей використання правових засобів інформаційного права та права інтелектуальної власності, а також інструментів цифрової економіки для врегулювання суспільних відносин у сфері інтелектуальної власності в Україні з урахуванням європейської інтеграції, розбудови інформаційного суспільства й інформаційного законодавства.

Відповідно до вимог методології наукового дослідження, для досягнення зазначеної мети висувається та перевіряється наступна наукова гіпотеза: необхідною умовою належного забезпечення права інтелектуальної власності в умовах розбудови суспільства знань в Україні є комплексне використання правових засобів інформаційного права й права інтелектуальної власності, інструментів цифрової економіки та відповідного досвіду ЄС.

Перед перевіркою зазначеної гіпотези вважаємо за доцільне зазначити, що варто розрізняти поняття правотворчості та правоутворення: правоутворення - це всі форми й засоби виникнення, розвитку та зміни права, включаючи правотворчість. Тобто правоутворення $є$ ширшим поняттям, ніж іiі результат - власне правотворчість ${ }^{14}$. Водночас на встановлення нових правових норм, а також зміну чинних чи скасування застарілих правових норм впливають різні фактори, наприклад, економічні, політичні. У разі нашого предмета дослідження на правотворчість у сфері інтелектуальної власності здійснюють вплив цифрова економіка (економічний фактор) і європейська інтеграція України (переважно політичний фактор). Згідно з наявною класифікацією етапів процесу правоутворення ${ }^{15}$, дослідження цих впливів пов'язано 3 матеріальним етапом. Тобто йдеться про те, що матеріальний етап

11 Арістова I.В., Курило В.І., Калугін О.Ю. Впровадження інформаційно-комунікаційних технологій в аграрний сектор економіки України: організаційно-правовий аспект : монографія / за заг. ред. І.В. Арістової. Київ : Редакційно-видавничий центр НУБіП України, 2014. $193 \mathrm{c}$.

12 Бєляков К.І. Інформатизація в Україні: проблеми організаційного-правового та наукового забезпечення : монографія. Київ : КВІЦ, 2008. 576 с.

13 Кудь О.О., Кучерявенко М.П., Смичок Є.М. Цифрові активи та їх економіко-правове регулювання : монографія. Харків : Право, 2019. 384 с.

14 Скакун О.Ф. Теорія держави і права (Енциклопедичний курс) : підручник. 2-е вид., перероб. і доп. Харків : Еспада, 2009. С. 422.

15 Там само. 
правоутворення передує правотворчості, оскільки для встановлення нових норм необхідні відповідні дослідження, зокрема щодо впливу цифрової економіки та європейської інтеграції на формування норм права у сфері інтелектуальної власності в Україні. У зв’язку з цим до структури статті будуть включені відповідні розділи - II і III.

У статті акцентовано увагу на необхідності розуміння змісту та структури поняття «правові засоби» (засоби правового регулювання). Це - «правові явища, що призначені для правового упорядкування суспільних відносин, оптимального вирішення соціальних завдань, досягнення суб'єктами правовідносин приватних та публічних цілей» ${ }^{16}$. Варто підкреслити, що поняття «засіб» містить у собі як інструментарій (засоби - встановлення), так і технології (засоби - діiі). До першого складника належать, наприклад, зобов’язання, дозволи, заборони, заохочення, рекомендації, покарання, пільги, норми права, принципи права тощо. Другий складник правових засобів включає акти реалізації права, акти застосування права й усі процеси юридичної діяльності ${ }^{17}$. До речі, наведені види правових засобів згруповано за критерієм регулятивної активності. Водночас за критерієм галузевої належності правові засоби поділяються на конституційні, адміністративні, цивільні, інформаційні тощо. Уважаємо за доцільне зазначити, що в процесі перевірки висунутої наукової гіпотези будуть використовуватися елементи наведених груп правових засобів.

На нашу думку, необхідно визначитися зі змістом ще декількох основних понять, які будуть використовуватися під час перевірки гіпотези, а також їх функціональними характеристиками. Отже, акцентуємо увагу на з'ясуванні змісту відносно нових понять: цифрова економіка, інформаційні технології, блокчейн, токен блокчейну, цифровий актив і смарт-контракт. Така пропозиція зумовлена їх впливом на розвиток цифрової економіки в Україні та забезпечення прав людини.

У класичному розумінні поняття «цифрова економіка» означає діяльність, у якій основними засобами (факторами) виробництва $\epsilon$ цифрові (електронні, віртуальні) дані, як числові, так і текстові ${ }^{18}$.

\footnotetext{
16 Скакун О.Ф. Теорія держави і права (Енциклопедичний курс) : підручник. 2-е вид., перероб. і доп. Харків : Еспада, 2009. С. 284.

17 Скакун О.Ф. Теорія держави і права (Енциклопедичний курс) : підручник. 2-е вид., перероб. і доп. Харків : Еспада, 2009. С. 285.

18 Про схвалення Концепції розвитку цифрової економіки та суспільства України на 2018-2020 роки та затвердження плану заходів щодо іiі реалізації : Розпорядження Кабінету Міністрів України від 17.01.2018 № 67-p. URL: https://www.kmu.gov.ua/npas/proshvalennya-koncepciyi-rozvitku-cifrovoyi-ekonomiki-ta-suspilstva-ukrayini-na-20182020-rokita-zatverdzhennya-planu-zahodiv-shodo-yiyi-realizaciyi (дата звернення: 15.02.2020).
} 
Цифрова економіка базується на інформаційно-комунікаційних технологіях, стрімкий розвиток яких уже сьогодні впливає на традиційну (фізично-аналогову) економіку, трансформуючи іiі від такої, що споживає ресурси, до економіки, що створює ресурси. Саме дані є ключовим ресурсом цифрової економіки, вони генеруються та забезпечують електронно-комунікаційну взаємодію завдяки функціонуванню електронно-цифрових пристроїв, засобів і систем. Шлях до цифрової економіки пролягає через внутрішній ринок виробництва, використання і споживання IКТ та цифрових. Варто зазначити, що впровадження IКТ, які являють собою сукупність методів, виробничих процесів і програмно-технічних засобів, інтегрованих $з$ метою збирання, обробки, зберігання, розповсюдження, демонстрації та використання даних в інтересах їх користувачів, послугували закономірними чинниками соціально-економічного посилення й забезпечення добробуту, комфорту і якості життя суспільства ${ }^{19}$.

Установлено, що блокчейн являє собою структуровану базу даних, «ланцюжок блоків», де кожен блок пов'язаний із попереднім. Блок містить набір записів (інформацію). Кожен новий блок з інформацією додається в кінець ланцюжка. Отже, створюється своєрідний «реєстр» даних, у який дані вносяться в суворій послідовності ${ }^{20}$. Кількість блоків $\epsilon$ необмеженою. Змістовно блок може містити будь-яку інформацію: про дії, людей, об'єкти, транзакції, серійні номери, видані кредити тощо. Іншими словами, блокчейн - це розподілений публічний реєстр, заснований на сучасних криптографічних алгоритмах, що містить базу даних про всі раніше здійснені операції, який мають децентралізований характер. Це структурована система з певними правилами побудови ланцюжків транзакцій і доступу до інформації ${ }^{21}$.

3'ясовано основоположні принципи функціонування технології блокчейн, а саме: розподіленість реєстру та функціонування його до останнього активного мережевого вузла; доступність до історії транзакцій усіх учасників; відсутність ієрархії; відкритість і захищеність даних користувачів; абсолютна прозорість; «довірчій»

19 Про схвалення Концепції розвитку цифрової економіки та суспільства України на 2018-2020 роки та затвердження плану заходів щодо іiі реалізації : Розпорядження Кабінету Міністрів від 17.01.2018 № 67-p. URL: https://www.kmu.gov.ua/npas/pro-shvalennya-koncepciyirozvitku-cifrovoyi-ekonomiki-ta-suspilstva-ukrayini-na-20182020-roki-ta-zatverdzhennya-planuzahodiv-shodo-yiyi-realizaciyi (дата звернення: 15.02.2020).

20 Что такое блокчейн простыми словами. URL: https://prostocoin.com/blog/blockchainguide (дата звернення: 15.02.2020).

21 Харитонов С.О., Харитонова О.І. ІТ-право: теорія та практика : навчальний посібник. 2-ге вид., доп. Одеса : Фенікс, 2019. С. 89. 
характер системи тощо 22 . Проведені дослідження ${ }^{23}$ дали змогу встановити, що ці принципи розкривають основні переваги цієї технології, а також значення блокчейну: ця технологія є дійсно запитуваною та перспективною майже в усіх сферах суспільного життя (державні реєстри, житлово-комунальне господарство, охорона здоров'я, фінанси, банківська сфера, медіа, юриспруденція, соціальне страхування, енергетика тощо).

У свою чергу, блокчейн як система обліку є технологією з криптографічно захищеного, хронологічно незмінного обліку транзакцій, під яким варто розуміти фіксацію всіх переходів одиниць обліку мережі блокчейн між користувачами такої мережі. Одиниця обліку, по суті, становить одиницю виміру певного ресурсу. При цьому як ресурс може виступати інформація, майно, право ${ }^{24}$. У мережі блокчейн такі одиниці обліку прийнято називати токенами або криптовалютами. Отже, під токеном блокчейну варто розуміти одиницю обліку розподіленого реєстру (блокчейну), що є частиною децентралізованого програмного протоколу.

Варто зазначити, що нині використовують кілька головних методик класифікації токенів блокчейну ${ }^{25}$, серед яких на особливу увагу заслуговує методика діагностики характеристик токену розподіленого реєстру (блокчейну) на відповідність цифровому активу. Аналіз цієї методики дав змогу переконатися, що ця класифікація надає якісний новий підхід до токену блокчейну як цифрового активу - інформаційного ресурсу, похідного від права на цінність. Крім цього, установлені сутнісно-смислові особливості поняття «цифровий актив» сприяли усвідомленню того, що цей інформаційний ресурс ще й обертається в розподіленому реєстрі у вигляді унікального ідентифікатора ${ }^{26}$. Уважаємо, що суттєвим результатом методики постає те, що з'явилася можливість використання токену блокчейну як цифрового активу фізичними особами та суб'єктами господарювання в межах чинного правового

\footnotetext{
22 Кудь О.О., Кучерявенко М.П., Смичок Є.М. Цифрові активи та їх економіко-правове регулювання : монографія. Харків : Право, 2019. С. 14.

23 Харитонов С.О., Харитонова О.І. IT-право: теорія та практика : навчальний посібник. 2-ге вид., доп. Одеса : Фенікс, 2019. С. 88.

24 Кудь О.О., Кучерявенко М.П., Смичок Є.М. Цифрові активи та їх економіко-правове регулювання : монографія. Харків : Право, 2019. С. 47.

25 Кудь О.О., Кучерявенко М.П., Смичок Є.М. Цифрові активи та їх економіко-правове регулювання : монографія. Харків : Право, 2019. С. 54.

26 Kud A.A. Substantiation of the term "digital asset": economic and legal aspects. International Journal of Education and Science. 2019. P. 4.
} 
поля ${ }^{27}$. Варто зазначити, що, на відміну від спекулятивного активу, основою ціноутворення буде виступати не фактор ажіотажу та паніки, а конкретна цінність, що в кінцевому результаті має призвести до формування глобального ринку інформаційних ресурсів, товарів і послуг на базі технології розподіленого реєстру ${ }^{28}$. I це, на нашу думку, варто підтримувати й упроваджувати.

Підсумовуючи вищесказане, можна зробити висновок, що закономірні комплексні властивості токену блокчейну зводяться до виконання однієї важливої функції - допуску до інформаційного ресурсу, який, у свою чергу, надає доступ до певного комплексу прав на цінність, під яким прийнято розуміти майно, майнові та немайнові права, цінні папери, послуги, роботи, цифрові активи тощо, що дійсно забезпечує належну безпеку власникам цифрових активів і водночас сприятливо позначається на економіці країни ${ }^{29}$.Тобто виникає реальна можливість охорони різноманітних прав людини за допомогою технології блокчейн і ії інструментів. Будемо вважати таку охорону технологічною. На нашу думку, наступні положення нашої роботи сприятимуть більшому усвідомленню такої позиції.

Беручи до уваги, що головне завдання блокчейну полягає в обліку, зберіганні та передаванні цінностей, є очевидним, що саме цінність у цьому контексті є однією з категорій технології блокчейн, на базі якої зароджуються та розвиваються нові відносини ${ }^{30}$. Дійсно, проведені дослідження сприяли усвідомленню того, що потенціал природи технології блокчейн здатен самостійно сприяти всебічному формуванню довірчих відносин у суспільстві, охоплюючи такі додаткові характеристики, як прозорість і фактичність, а також гарантуванню принципу рівності, що дійсно є дуже актуальним для суспільства натепер, особливо у зв'язку з необхідністю охорони прав людини.

Варто зазначити, що нині питання правового врегулювання цих взаємовідносин гостро постали перед законодавцями в аспекті ліквідації їх анонімного фактору. Для вирішення цієї проблеми запропоновано підхід, який включає ідентифікацію та верифікацію ${ }^{31}$.

27 Кудь О.О., Кучерявенко М.П., Смичок Є.М. Цифрові активи та їх економіко-правове регулювання : монографія. Харків : Право, 2019. С. 71.

28 Кудь О.О., Кучерявенко М.П., Смичок Є.М. Цифрові активи та їх економіко-правове регулювання : монографія. Харків : Право, 2019. С. 73.

29 Там само.

30 Кудь О.О., Кучерявенко М.П., Смичок Є.М. Цифрові активи та їх економіко-правове регулювання : монографія. Харків : Право, 2019. С. 80.

31 Кудь О.О., Кучерявенко М.П., Смичок Є.М. Цифрові активи та їх економіко-правове регулювання : монографія. Харків : Право, 2019. С. 88. 
Установлено, що низка колізій і прогалин у законодавстві, зокрема й пов'язаних з обробленням персональних даних, здатна ліквідуватися шляхом адаптування та синхронізації чинних норм до технології блокчейн ${ }^{32}$. На нашу думку, ідеться про необхідність комплексного врахування правової та технологічної охорони прав людини в умовах цифрової економіки.

Проведені дослідження дали змогу встановити, що кількість сфер щодо практичного застосування блокчейну є досить значною. Варто підкреслити, що ми переконалися в тому, що інноваційна технологія дійсно містить безліч функціональних можливостей, зокрема дає змогу вести облік як інформації, так і прав, поданих у вигляді інформаційного ресурсу, а також бути середовищем обертання цих прав ${ }^{33}$. Дійсно, оскільки цифровий актив є засобом використання інформації, у тому числі інформації про комплекс прав, то можна стверджувати, що завдяки блокчейну в обертанні знаходиться інформація про право. У такому разі цивільне обертання прав здійснюється в кіберфізичному просторі та не має географічних меж ${ }^{34}$. Як показали дослідження ${ }^{35}$, надзвичайно ефективно блокчейн може бути застосований у сфері прав інтелектуальної власності, що ц буде перевірено під час дослідження.

Уважаємо за необхідне дослідити нові перспективні можливості технології блокчейн передусім в аспекті впровадження смарт-контрактів на базі розподіленого реєстру. Установлено, що з розвитком ІКТ постало питання щодо спрощення та надійності системи укладання й виконання різного роду контрактів (договорів) шляхом реалізації концепції смарт-контрактів. Як довели дослідження, смарт-контрактами є угоди, написані в коді, які автоматично виконують запрограмовані функції у відповідь на певні умови, що виконуються сторонами угоди ${ }^{36}$. Важливо, що смарт-контракт - це контракт на даних розподіленого реєстру блокчейн, де використовується принцип

\footnotetext{
32 Кудь О.О., Кучерявенко М.П., Смичок Є.М. Цифрові активи та їх економіко-правове регулювання : монографія. Харків : Право, 2019. С. 91.

33 Кудь О.О., Кучерявенко М.П., Смичок Є.М. Цифрові активи та їх економіко-правове регулювання : монографія. Харків : Право, 2019. С. 293.

34 Кудь О.О., Кучерявенко М.П., Смичок Є.М. Цифрові активи та їх економіко-правове регулювання : монографія. Харків : Право, 2019. С. 295.

35 Кудь О.О., Кучерявенко М.П., Смичок С.М. Цифрові активи та їх економіко-правове регулювання : монографія. Харків : Право, 2019. С. 293.

36 Бойко H.O. Смарт контракти - чи справді договори та чи дійсно «розумні». URL: https://unba.org.ua/publications/3169-smart-kontrakti--chi-spravdi-dogovori-ta-chi-dijsnorozumni.html (дата звернення: 15.02.2020).
} 
«якщо ..., то», тобто умова прямо визначена в контракті ${ }^{37}$. Варто зазначити, що, якщо смарт-контракту потрібен звязок із зовнішнім світом (банками, реєстрами тощо), використовують оракули - сервіси, які відповідають за підключення до джерела даних. Аналіз засвідчив, що за допомогою оракула розумний контракт отримує доступ до інформації в онлайн-режимі й може дізнатися про поточний курс валют, зміну цін, статус платежу тощо. Отже, так звані оракули виступають у ролі посередників, оскільки повідомляють смарт-контракту про настання тієї чи іншої події, яка впливає на виконання програмного алгоритму ${ }^{38}$.

Проведені дослідження дали змогу дійти висновку, що, використовуючи смарт-контракти, можна спростити діяльність у багатьох сферах життя, у тому числі в юриспруденції, а саме під час охорони права інтелектуальної власності. У роботі поділяється думка O.I. Харитонової, що на етапі повноцінного становлення смарт-контрактів на базі технології блокчейну, в тому числі набуття ними правового статусу, у нагоді можуть стати «медіатори» - юристи нового покоління - «блокчейн-юристи». При цьому наголошується, що юристам майбутнього необхідні знання основ програмування, аби вони могли створювати смарт-контракти на основі блокчейну ${ }^{39}$. Уважаємо, що цей приклад переконливо доводить, що технологічна охорона будь-яких прав людини водночас потребує й своєрідної правової підтримки.

Під час дослідження з'ясовано, що, з огляду на властивості цифрового активу в розподіленому реєстрі, реєстрація об'єктів права інтелектуальної власності в блокчейні у вигляді інформаційних ресурсів (оцифровування) дає можливість власникам авторських прав уникнути плагіату, «піратського» розповсюдження, надає контролінг за легальністю розповсюдження результатів творчої та наукової діяльності (музичних творів, статей, наукових досліджень тощо) через обертання цифрових активів, у які закладено ці об'єкти прав інтелектуальної власності ${ }^{40}$. I це, на наш погляд, є наступним напрямом перспективного впровадження технології блокчейн задля технологічної охорони права інтелектуальної власності.

37 Харитонов С.О., Харитонова О.І. IT-право: теорія та практика : навчальний посібник. 2-ге вид., доп. Одеса : Фенікс, 2019. С. 102.

38 Солодовников Н.В. Смарт-контракты: как они работают и зачем нужны. URL: https://www.pgplaw.ru/news/comments-in-the-media/smart-contracts-how-they-work-and-whyyou-need (дата звернення: 13.02.2020).

39 Харитонов С.О., Харитонова О.І. ІT-право: теорія та практика : навчальний посібник. 2-ге вид., доп. Одеса : Фенікс, 2019. С. 47.

40 Кудь О.О., Кучерявенко М.П., Смичок С.М. Цифрові активи та їх економіко-правове регулювання : монографія. Харків : Право, 2019. С. 294. 


\section{2. Інтелектуальна власність}

\section{в умовах інформаційного суспільства в Україні:}

\section{місце правотворчості й інструментів цифрової економіки}

Проведені дослідження сприяли усвідомленню того, що існують різні підходи до розуміння поняття права інтелектуальної власності, тому в роботі пропонуємо дотримуватися такої дефініції: «Інтелектуальна власність - термін, який склався історично, є умовним і має тільки термінологічну схожість із правом власності в його традиційному сприйманні й повинен розумітися як сукупність виключних прав особистого та майнового характеру на результати інтелектуальної діяльності» ${ }^{41}$, котрі не $є$ правами власника. «Відповідно до такого бачення, право на об'єкти інтелектуальної власності складається 3 двох правомочностей: право забороняти й/ чи дозволяти їх використання третім особам» ${ }^{42}$. Водночас варто зазначити, що $є$ прихильники позиції, які співвідносять право інтелектуальної власності з власністю віртуальною в реальному світі, де йдеться не про право на річ, а про право на права ${ }^{43}$.

Варто зазначити, що Цивільний кодекс (далі - ЦК) України визначає право інтелектуальної власності (далі - IB) як право особи на результат інтелектуальної, творчої діяльності або на інший об'єкт права IB, визначений законом (ч. 1 ст. 418) $)^{44}$. Відомо ${ }^{45}$, що право IB варто розглядати у двох значеннях: об'єктивному та суб'єктивному.

На нашу думку, необхідно встановити, що постає фундаментом правової охорони об'єктів права IB. 3'ясовано, що правові засади розвитку творчої діяльності людини й охорони іiі результатів закладені в Конституцію України ${ }^{46}$, ЦК України ${ }^{47}$, закони України: «Про авторське

41 Сергеев А.П. Право интеллектуальной собственности в Российской Федерации : учебник. Москва : Проспект, 1996. С. 14, 18-19.

42 Харитонов С.О., Харитонова О.І. IT-право: теорія та практика : навчальний посібник. 2-ге вид., доп. Одеса : Фенікс, 2019. С. 218.

43 Харитонов С.О., Харитонова О.I. IT-право: теорія та практика: навчальний посібник. 2-ге вид., доп. Одеса : Фенікс, 2019. С. 216.

44 Цивільний кодекс України : Закон України від 16.01.2003 № 435-IV. Відомості Верховної Ради Украӥни. 2003. № 40-44. Ст. 418.

45 Баранова Л.М., Бєгова Т.І. Цивільне право : підручник : у 2 т. / за ред. В.І. Борисової, І.В. Спасибо-Фатєєвої, В.Л. Яроцького. Харків : Право, 2011. Т. 1. С. 535.

46 Конституція України : Закон України від 28 червня 1996 р. № 254к/96-ВР. Відомості Верховної Ради України. 1996. № 30. Ст. 141.

47 Цивільний кодекс України : Закон України від 16.01.2003 № 435-IV. Вiдомості Верховної Ради Украӥни. 2003. № 40-44. Ст. 356. 
право і суміжні права» ${ }^{48}$, «Про охорону прав на винаходи і корисні моделі $»^{49}$, «Про охорону прав на сорти рослин» тощо. Серед міжнародних актів - Бернська конвенція про охорону літературних і художніх творів 1886 р. (Паризький акт від 24.07.1971), Всесвітня конвенція про авторське право 1952 p.

Безумовно, у теорії права об'єктом прийнято вважати матеріальні й нематеріальні блага, з приводу яких виникають правовідносини. Із цього випливає, що це саме правило стосується й об'єктів права IB. Варто підкреслити, що загальні норми насамперед визначають коло об'єктів права IB. Як показали дослідження ${ }^{50}$, перелік об' єктів права IB вперше легалізований на міжнародному рівні в Конвенції про заснування Всесвітньої організації інтелектуальної власності. Ми переконалися, що ст. 420 ЦК України до них зараховує літературні та художні твори, комп'ютерні програми, компіляції даних (бази даних); виконання; фонограми, відеограми, передачі (програми) організацій мовлення; наукові відкриття; винаходи, корисні моделі, промислові зразки; компонування (топографії) інтегральних мікросхем; раціоналізаторські пропозиції; сорти рослин та породи тварин; комерційні (фірмові) найменування, торговельні марки (знаки для товарів і послуг), географічні зазначення; комерційні таємниці ${ }^{51}$. Тобто в ЦК України значною мірою відтворено перелік об'єктів права IB, указаний у Стокгольмській конвенції.

Дослідження ${ }^{52}$ сприяли усвідомленню того, що під час регулювання відносин, що насамперед пов'язані зі створенням, використанням та охороною об'єктів авторського права й водночас промислової власності, виникає, з одного боку, багато спільного, а з іншого - відмінного ${ }^{53}$. Зокрема, відмінності регулювання цих відносин пропонують пов'язувати зі сферами інтелектуальної діяльності, різними строками

48 Про авторське право і суміжні права : Закон України від 23.12.1993 № 3792-XII. URL: https://zakon.rada.gov.ua/laws/show/3792-12 (дата звернення: 01.02.2020).

49 Про охорону прав на винаходи і корисні моделі: Закон України від 15.12.1993 № 3687-XII. URL: https://zakon.rada.gov.ua/laws/card/3687-12 (дата звернення: 15.02.2020).

50 Яновицька Г.Б., Кучер В.О. Цивільне право України : підручник: у 2 т. / за ред. Г.Б. Яновицької, В.О. Кучера. Львів : Новий Світ-2000, 2014. Т. 1. С. 387.

51 Цивільний кодекс України : Закон України від 16.01.2003 № 435-IV. Вiдомості Верховної Ради Украӥни. 2003. № 40-44. Ст. 356.

52 Яновицька Г.Б., Кучер В.О. Цивільне право України : підручник : у 2 т. / за ред. Г.Б. Яновицької, В.О. Кучера. Львів : Новий Світ-2000, 2014. Т. 1. 444 с.

53 Яновицька Г.Б., Кучер В.О. Цивільне право України : підручник: у 2 т. / за ред. Г.Б. Яновицької, В.О. Кучера. Львів : Новий Світ-2000, 2014. Т. 1. С. 386. 
дії відповідно до авторського й патентного права ${ }^{54}$. Отже, відмінність цих об'єктів зумовлюється особливостями їх правової охорони. Для здійснення інтелектуальних прав істотне значення має визначення моменту їх виникнення. Правова охорона інтелектуального продукту базується на двох основних правилах щодо виникнення виключних прав на нього: правило фактичного створення об'єкта IB, з яким і збігається момент виникнення виключних прав, і дотримання формальностей як умови виникнення виключних прав ${ }^{55}$.

Правова охорона об'єктів IB здійснюється за допомогою надання ïх створювачу виключних прав. Під виключним правом прийнято вважати виключну можливість здійснювати щодо об'єкта закріплені законом правомочності на власний розсуд ${ }^{56}$. Правова система охорони об'єктів IB побудована на принципі поєднання інтересів створювача інтелектуального продукту та інтересів суспільства. Цей принцип у загальному вигляді втілений у норму ч. 2 ст. 424 ЦК України ${ }^{57}$.

Проведені дослідження дали змогу встановити, що будь-який об'єкт права IB, у якому фігурують інтелектуальні цінності або блага, створені інтелектуальною працею, несе певне інформаційне навантаження. Дійсно, інформація, у якій відображено розуміння тими чи іншими суб'єктами навколишньої дійсності, є тим об'єднувальним фактором, який поєднує всі об'єкти права $\mathrm{IB}^{58}$. Дійсно, є підстави усвідомлювати те, що інститут виключних прав цілком присвячений регулюванню правового режиму інформації. 3 останнього твердження випливає перше, адже творча праця є видом інтелектуальної діяльності, а продуктом останньої є інформація, яка, у свою чергу, $\epsilon$ специфічною формою надання правової охорони результатам інтелектуальної діяльності ${ }^{59}$.

У межах роботи пропонуємо акцентувати увагу на об'єктах права IB в діяльності IT-компаній. Готовий ІТ-продукт охороняється, від-

54 Яновицька Г.Б., Кучер В.О. Цивільне право України : підручник : у 2 т. / за ред. Г.Б. Яновицької, В.О. Кучера. Львів : Новий Світ-2000, 2014. Т. 1. С. 387.

55 Баранова Л.М., Бєгова Т.І. Цивільне право : підручник : у 2 т. / за ред. В.І. Борисової, І.В. Спасибо-Фатєєвої, В.Л. Яроцького. Харків : Право, 2011. Т. 1. С. 535.

56 Баранова Л.М., Бєгова Т.І. Цивільне право : підручник : у 2 т. / за ред. В.І. Борисової, І.В. Спасибо-Фатєєвої, В.Л. Яроцького. Харків : Право, 2011. Т. 1. С. 539.

57 Цивільний кодекс України : Закон України від 16.01.2003 № 435-IV. Вiдомості Верховної Ради України. 2003. № 40-44. Ст. 224.

58 Яновицька Г.Б., Кучер В.О. Цивільне право України : підручник: у 2 т. / за ред. Г.Б. Яновицької, В.О. Кучера. Львів : Новий Світ-2000, 2014. Т. 1. С. 387.

59 Яновицька Г.Б., Кучер В.О. Цивільне право України : підручник : у 2 т. / за ред. Г.Б. Яновицької, В.О. Кучера. Львів : Новий Світ-2000, 2014. Т. 1. С. 388. 
повідно до Закону України «Про авторське право та суміжні права», як літературний твір. Крім цього, згідно зі ст. 4 Договору Всесвітньої організації інтелектуальної власності про авторське право (1996р.), комп'ютерні програми та бази даних охороняються як літературні твори в розумінні ст. 2 Бернської конвенції про охорону літературних і художніх творів ${ }^{60}$.Така охорона застосовується до комп'ютерних програм незалежно від способу або форми їх вираження ${ }^{61}$. Проведені дослідження дали можливість установити, що в аспекті авторського права ці ІТ-продукти створюються інтелектуальною творчою працею автора або співавторів твору, які виражені в об'єктивній формі. Підкреслимо, що автором такого ІТ-продукту може бути лише фізична особа, творчою працею якої є створений продукт. Тобто юридична особа автором такого продукту не може бути, однак може створювати організаційні, матеріальні умови для творчої праці фізичної особи спеціаліста, котрий і створює IT-продукт.

Проведені дослідження дали змогу встановити, що майнові права на зазначені ІТ-продукти дуже рідко належать самим авторам: дійсно, пишуть комп'ютерні програми програмісти, а володіють майновими правами переважно роботодавці або треті особи (замовники). Варто зазначити, що використання майнових авторських прав на програмні продукти завжди вимагає укладення авторських договорів ${ }^{62}$. Виходячи 3 положень ст. 31 Закону України «Про авторське право і суміжні права», необхідно усвідомлювати, що майнові права, не вказані в авторському договорі як відчужувані, уважаються непереданими ${ }^{63}$.

Зазначене вище сприяло усвідомленню того, що надзвичайно важливим є оформлення передачі майнових прав на комп'ютерну програму чи базу даних у відносинах, що підпадають під сферу службового твору. Так, виключне майнове право на службовий твір належить роботодавцю, якщо інше не передбачено трудовим

60 Бернська конвенція про охорону літературних і художніх творів (Паризький акт від 24 липня 1971 р., змінений 2 жовтня 1979 р.). URL: https://zakon.rada.gov.ua/laws/ show/995_051 (дата звернення: 15.02.2020).

61 Жуванов Д.М., Стогній Є.С. Яку форму правової охорони обрати для комп’ютерної програми? URL: https://romanenko.biz/ua/publikatsii/41-publications-copyright-ua/106-yakuformu-pravovoji-okhoroni-obrati-dlya-komp-yuternoji-programi (дата звернення: 13.02.2020).

62 Коваль М.С. Права інтелектуальної власності на створений IT-продукт: проблемні моменти. URL: http:/uz.ligazakon.ua/ua/magazine_article/EA009095 (дата звернення: 15.02.2020).

63 Про авторське право і суміжні права : Закон України від 23.12.1993 № 3792-XII. URL: https://zakon.rada.gov.ua/laws/show/3792-12 (дата звернення: 15.02.2020). 
договором (контрактом) та (або) цивільно-правовим договором між автором і роботодавцем ${ }^{64}$.

Під час дослідження встановлено, що авторським правом охороняється втілення об'єктів творчої діяльності IT-компаній у матеріальній формі, однак сам зміст продукту не підлягає охороні. Разом із тим з'ясовано, що з метою охорони (захисту) саме ідеї, а не лише форми вираження необхідно комп'ютерні програми та бази даних захищати як винаходи або корисні моделі ${ }^{65}$. Варто зазначити, що кожна держава встановлює критерії для визнання результату творчої діяльності саме об'єктом патентного права. Аналіз літератури ${ }^{66}$ дав можливість 3'ясувати, що в Україні правова охорона надається винаходу, корисній моделі та промисловому зразку, які не суперечать публічному порядку, принципам гуманності й моралі та відповідають умовам патентоздатності. Тобто вимогам, передбаченим законодавством для підтвердження кваліфікації зазначених результатів саме як об'єктів патентного права, які складаються 3 критеріїв: новизна, винахідницький рівень і промислова придатність у тому чи іншому їх поєднанні ${ }^{67}$.

Доречно сказати, що оскільки комп'ютерні програми та бази даних є об'єктами права IB, то в результаті їх створення виникають дві групи прав: особисті немайнові та майнові права інтелектуальної власності. Немайнові права виникають на будь-який об'єкт IB з моменту створення такого об'єкта. Водночас майнові права на винахід, корисну модель, промисловий зразок визначено в ст. 464 ЦК України ${ }^{68}$. Патент надає його власнику виключне право використовувати винахід, корисну модель чи промисловий зразок за своїм розсудом, якщо таке використання не порушує прав інших власників патентів. Взаємовідносини під час використання об'єкта, патент на який належить кільком особам, визначаються угодою між ними. У разі відсутності такої угоди кожний власник патенту може використовувати його за своїм розсудом, але жоден із них не має права

64 Про авторське право і суміжні права: Закон України від 23.12.1993 № 3792-XII. URL: https://zakon.rada.gov.ua/laws/show/3792-12 (дата звернення: 15.02.2020).

65 Там само.

66 Яновицька Г.Б., Кучер В.О. Цивільне право України : підручник: у 2 т. / за ред. Г.Б. Яновицької, В.О. Кучера. Львів : Новий Світ-2000, 2014. Т. 1. С. 410.

${ }_{67}$ Баранова Л.М., Бєгова Т.І. Цивільне право : підручник : у 2 т. / за ред. В.І. Борисової, І.В. Спасибо-Фатєєвої, В.Л. Яроцького. Харків : Право, 2011. Т. 1. С. 581.

68 Цивільний кодекс України : Закон України від 16.01.2003 № 435-IV. Відомості Верховної Ради України. 2003. № 40-44. Ст. 464. 
давати дозвіл на використання та передавати право власності на об’єкт іншій особі без згоди інших власників патенту ${ }^{69}$. Майнові права IB на винахід, корисну модель, промисловий зразок є чинними з дати їх державної реєстрації в тій країні, де особа бажає отримати патент, за умови підтримання чинності цих прав відповідно до закону ${ }^{70}$. Тобто ми переконалися в існуванні правової охорони об'єктів права IB, що є продуктом IT-компанії.

Варто зазначити, що функції патентування тих чи інших об'єктів права IB здійснює Державне підприємство «Український інститут інтелектуальної власності» (Укрпатент), який у разі подачі відповідної заяви на патент проводить низку процедур: від експертизи відповідного продукту до державної реєстрації та видачі відповідної ліцензії ${ }^{71}$. До речі, в Україні як загальне правило діє вимога абсолютної світової новизни.

У роботі досліджено патенти IT-компанії в Україні - Simcord ${ }^{72}$, яка за багатьма показниками своєї діяльності претендує на першість у світі. Дослідження показали, що такий спосіб охорони IB, а точніше, майнових прав на розроблений продукт, як патентування, розвинений у нашій країні та має низку пріоритетів як спосіб, який гарантує безпеку прав. Зокрема, установлено, що отримано патент «Спосіб здійснення транзакції з передачі цифрової цінності (цифрового активу) та система передачі цифрових цінностей для його здійснення» (The Method for Executing a Digital Value Transfer Transaction and the Digital Value Transfer System for Its Implementation) за номером заявки 2019/0708.2, який підтверджує новаторський підхід до реалізації технологічних процесів під час здійснення транзакції з передачі цифрових активів i засвідчує виключні права на винайдення системи для реалізації заявленого способу. 3'ясовано, що цей патент зареєстрований у Казахстані ${ }^{73}$. Проведені дослідження сприяли

\footnotetext{
69 Баранова Л.М., Бєгова Т.І. Цивільне право : підручник : у 2 т. / за ред. В.І. Борисової, I.В. Спасибо-Фатєєвої, В.Л. Яроцького. Харків : Право, 2011. Т. 1. С. 590.

70 Цивільний кодекс України : Закон України від 16.01.2003 № 435-IV. Відомості Верховної Ради Украӥни. 2003. № 40-44. Ст. 356.

71 Офіційний сайт Українського інституту інтелектуальної власності. URL: https://ukrpatent.org/uk (дата звернення: 15.02.2020).

72 Офіційний сайт компанії Simcord. URL: https://www.simcord.com/ua/legal-informationpatents (дата звернення: 15.02.2020).

73 Патент на винахід «Спосіб здійснення транзакції з передачі цифрової цінності (цифрового активу) та система передачі цифрових цінностей для його здійснення». Офіційний сайт компанії Simcord. URL: https://www.simcord.com/ua/legal-information-patents (дата звернення: 15.02.2020).
} 
усвідомленню того, що реєстрація IB, а також розроблені фахівцями компаніï Simcord апаратно-програмні комплекси гарантують забезпечення цифрового активу та формують надійний фундамент інформаційних платформ, зокрема й Системи Bitbon ${ }^{74}$ (ідеться про правову охорону права IB цієї компанії).

В аспекті правового врегулювання відносин щодо цифрових продуктів, які постають об'єктами права IB IT-компаній, виникає потреба звернутися до зобов'язального законодавства. Оскільки IT-компанії зазвичай займаються розробленням програмного забезпечення або бази даних за замовленням, то велике значення має саме врегулювання питань щодо майнових прав на ці новостворені продукти, які є об'єктами права інтелектуальної власності. Аналіз положень ЦК України дав змогу з'ясувати, що в главі 75 закріплено норми щодо розпорядження майновими правами $\mathrm{IB}^{75}$. Очевидно, що це $\epsilon$ прикладом правової охорони, яка відбувається традиційним способом - у письмовому вигляді.

На нашу думку, вельми цікавим є приклад правової охорони права IB, а саме договору про передання виключних майнових прав IB. Це перша у світі угода між українськими компаніями з купівлі-продажу токену блокчейну Bitbon як нематеріального активу, яка відбулася 04.12.201976. Наявність у суб' єкта цифрового активу надає йому право на доступ до інформаційного ресурсу, що містить інформацію про комплекс прав на цінність і відомості про зобов' язання власника цінності, виконання яких він має право вимагати. Водночас об'єктом взаємовідносин під час передавання цифрового активу $є$ інформація про цінність, виражена в інформаційному ресурсі, а саме передавання здійснюється через поступку права на доступ до такого інформаційного ресурсу ${ }^{77}$.

Проведені дослідження дали можливість установити, що компанія Project Consulting Group придбала в компанії Simcord 100 Bitbon на суму 16757 грн (еквівалентну 700 доларам США з розрахунку 1 Bitbon дорівнює 7 доларам США). Варто зазначити,

74 Система Bitbon. Офіційний сайт компанії Simcord. URL: https://www.simcord.com/ua/ bitbon-system (дата звернення: 15.02.2020).

75 Цивільний кодекс України : Закон України від 16.01.2003 № 435-IV. Відомості Верховної Ради Украӥни. 2003. № 40-44. Ст. 464.

76 Система Bitbon. Офіційний сайт компанії Simcord. URL: https://www.simcord.com/ua/ bitbon-system (дата звернення: 15.02.2020).

77 Кудь О.О., Кучерявенко М.П., Смичок С.М. Цифрові активи та їх економіко-правове регулювання : монографія. Харків : Право, 2019. С. 126. 
що в такий спосіб здійснено переуступку прав доступу до сервісів Системи Bitbon (об'єктів права IB) в обсязі $0,0001 \%{ }^{78}$, що є доказом і прикладом застосування норм чинного законодавства, тобто зобов'язальної юрисдикції без спеціальних регулятивних механізмів $^{79}$. Більше того, такі договори можуть виступати як спосіб захисту своїх майнових прав IB. У роботі поділяється позиція, що розгляд основної властивості цифрового активу та виявлений зв'язок між цифровим активом як одиницею обсягу допуску (права на доступ) до інформаційного ресурсу та правом власності на цінність дає змогу говорити про новий об'єкт цивільних правовідносин - право на користування інформацією, похідною від права на цінність ${ }^{80}$. Водночас уважаємо, що реалізації цивільного правовідношення сприяє інформаційне правовідношення, так зване забезпечувальне. На нашу думку, варто досліджувати доцільність формування комплексних правовідносин.

Варто підкреслити, що в попередніх роботах одного з авторів статті (зокрема у роботі ${ }^{81}$ ) викладено й обгрунтовано зазначену вище позицію. Уважаємо за доцільне навести окремі положення роботи ${ }^{82}$. По-перше, запропоновано в межах науки «інформаційне право» розвинути «інформаційну концепцію права» як вчення про інформаційну сутність права, яке свого часу запропоновано А.В. Венгеровим ${ }^{83}$. Усвідомлення змісту введеного поняття «інтегративна інформаційна сфері» дало змогу розглядати цю сферу як правову сферу суспільства, що «пронизана» інформацією в умовах інформаційного суспільства. По-друге, обгрунтовано потребу в дослідженні правової сфери з позиції системного підходу. Передусім акцентувалася увага на одному з фундаментальних положень загальної теорії

78 Перша у світі угода між українськими компаніями 3 купівлі-продажу точену блокчейну Bitbon як нематеріального активу офіційний сайт компанії Simcord. URL: https:/www.simcord.com/ua/news/first-buy-and-sell-transaction-of-the-bitbon-blockchaintoken-as-an-intangible-asset-between-ukrainian-companies-in-the-world (дата звернення: 15.02.2020).

79 Там само.

80 Кудь О.О., Кучерявенко М.П., Смичок Є.М. Цифрові активи та їх економіко-правове регулювання : монографія. Харків : Право, 2019. С. 330.

81 Арістова І.В. Теоретико-правові засади інформаційних правовідносин. Юридична відповідальність за правопорушення в інформаційній сфері та основи інформачійної деліктології : колективна монографія. Київ : КВУЦ, 2019. С. 18.

82 Там само.

83 Венгеров А.Б. Теория государства и права : учебник для юридических вузов. 3-е изд. Москва : Юриспруденция, 1999. 528 с. 
функціональних систем, відповідно до якого саме «система» постає тим ізоморфним принципом, який проникає через усі кордони, що історично склалися між різними науками ${ }^{84}$. Важливо, що системоутворювальним чинником правової системи є мета - «забезпечення належного правопорядку в суспільстві».

По-третє, установлено, що правова система («за предметом правового регулювання») включає різні сфери (підсистеми) суспільних відносин, які є предметом правового регулювання різних галузей права - адміністративного, цивільного, інформаційного тощо. При цьому кожна підсистема має зробити свій «внесок»у досягнення зазначеного результату (мети), корисно взаємодіючи з іншими підсистемами. По-четверте, у сучасних умовах розвитку інформаційного суспільства не лише збільшується обсяг інформації (зокрема правової), а й усвідомлюється іiі значення та роль у процесах соціальної взаємодії. Зазначена тенденція, серед іншого, вплинула й на виникнення інформаційної сфери - сфери суспільних інформаційних відносин, і на отримання стрімкої динаміки формування інформаційних відносин, і на формування потреби в їх упорядкуванні за допомогою відповідних норм - норм інформаційного права. Ураховуючи те що інформація «проникає в усі сфери суспільних відносин», підкреслювалося, що саме наука інформаційного права покликана очолити науковий пошук шляхів ефективного досягнення мети формування та функціонування правової сфери.

По-п'яте, переходячи від загального до конкретного, доведено доцільність дослідження одного з правових засобів механізму правового регулювання - правовідносин з позиції загальної теорії функціональних систем. При цьому мета так саме має бути системоутворювальним чинником. Якщо мета не може бути досягнута в межах одного (простого) правовідношення, то формується складне правовідношення, зокрема комплексне. Останнє правовідношення включає різнорідні галузеві правовідносини, наприклад, цивільне та інформаційне. Варто звернути увагу на те, що цивільне може поставати основним, оскільки мета пов'язана зі сферою інтелектуальної власності. Водночас інформаційне правовідношення $є$ забезпечувальним, оскільки допомагає здійсненню цивільного правовідношення. Тобто це приклад взаємодії сфери інтелектуальної власності та інформаційної сфери. До речі, аналогічна модель формується в разі взаємодії інформаційної сфери

\footnotetext{
84 Анохин П.К. Принципиальные вопросы общей теории функциональных систем : монография. URL: https://goo.gl/hgbmvz (дата звернення: 15.02.2020).
} 
3 іншими сферами суспільних відносин. Отже, як зазначено в роботі ${ }^{85}$, існують усі підстави вважати правову сферу в умовах інформаційного суспільства інтегративною інформаційною сферою.

Як показали дослідження, ще одним важливим аспектом у сфері охорони права IB, зокрема технологічної, є так звані смарт-контракти, пов'язані з використанням цифрових активів, а також здійсненням волевиявлення та виконання зобов'язань учасників таких відносин ${ }^{86}$. Вище вже розкрито особливості смарт-контрактів: вони вважаються виконаними від моменту здійснення транзакції завдяки природі технології блокчейн. Звідси випливає, що з появою розумних контрактів убачається можливим укладання угод і виконання зобов'язань у новій автоматизованій формі ${ }^{87}$. Підсумовуючи сказане, варто наголосити, що смарт-контракт може бути використаний не лише як альтернатива цивільному договору в письмовій формі, а й у вигляді доказу на підтвердження того чи іншого юридичного факту, наприклад, майнових прав. До того ж однією з переваг смарт-контрактів на базі технології блокчейн $є$ їх спроможність щодо захисту конфіденційності й особистої інформації про особу, що укладає цей контракт ${ }^{88}$.

Отже, у другій частині статті надано загальну характеристику місця: 1) правотворчості, тобто відповідних правових засобів права інтелектуальної власності й інформаційного права, у забезпеченні охорони права інтелектуальної власності IT-компаній - «правова охорона»; 2) інструментів цифрової економіки (блокчейн, цифровий актив, смарт-контракт, токен блокчейну) у забезпеченні охорони права інтелектуальної власності в умовах інформаційного суспільства - «технологічна охорона».

\footnotetext{
85 Арістова І.В. Теоретико-правові засади інформаційних правовідносин. Юридична відповідальність за правопорушення в інформачійній сфері та основи інформачійної деліктології : колективна монографія. Київ : КВУЦ, 2019. С. 15.

86 Дмитриева Г.К. Цифровые финансовые активы: проблемы коллизионного регулирования. Актуальные проблемы российского права. 2019. № 5 (102). С. 121.

87 Кудь О.О., Кучерявенко М.П., Смичок Є.М. Цифрові активи та їх економіко-правове регулювання : монографія. Харків : Право, 2019. С. 328.

88 Кудь О.О., Кучерявенко М.П., Смичок С.М. Цифрові активи та їх економіко-правове регулювання : монографія. Харків : Право, 2019. С. 327.
} 


\section{3. Інтелектуальна власність у Свропейському Союзі в умовах інформаційного суспільства: стан правотворчості й досвід для України}

У межах концепції дослідження пропонуємо дослідити стан правотворчості у сфері інтелектуальної власності країн ЄС в умовах інформаційного суспільства, а також з'ясувати можливості запозичення Україною позитивного досвіду цих країн щодо забезпечення права інтелектуальної власності з урахуванням глобалізації цифрової економіки. На нашу думку, це може стати в нагоді в процесі впровадження високих стандартів охорони права інтелектуальної власності (далі - IB) фізичних і юридичних осіб на національному рівні. Проведені дослідження дали можливість переконатися, що право інтелектуальної власності ЄС, попри довгий шлях свого становлення, включаючи процеси уніфікації та гармонізації законодавства держав-членів $Є C$, дійсно, характеризується досить ефективною системою охорони цього права ${ }^{89}$.

Варто зазначити, що система охорони права інтелектуальної власності в ЄС здійснює провідний вплив на законодавство інших країн Європи внаслідок усе більшої інтеграції цифрової економіки таких країн із СС, укладання СС угод про партнерство і співробітництво або про асоціацію ${ }^{90}$. Як показали дослідження, особливу роль досвід держав-членів СС має для України, що відображено й в Угоді про асоціацію ${ }^{91}$, глава 9 якої присвячена саме IB.

Аналіз літератури ${ }^{92}$ дав змогу з'ясувати, що під інтелектуальною власністю, відповідно до практик Всесвітньої організації інтелектуальної власності (далі - ВОІВ) і Світової організації торгівлі (далі СОТ), пропонують розуміти водночас як промислову власність, так і сферу авторських і суміжних прав. Отже, права інтелектуальної власності мають подвійний зміст: вони надають виключні майнові права, а також (більшою мірою стосовно авторських прав і меншою мірою стосовно промислової власності) особисті або немайнові права.

89 Капіца Ю.М. Уніфікація і гармонізація законодавства з охорони прав інтелектуальної власності держав-членів ЄС та законодавства України : автореф. дис. ... докт. юрид. наук : 12.00.03. Київ, 2019. С. 1.

90 Там само.

91 Угода про асоціацію між Україною, з однієї сторони, та Європейським Союзом, Європейським співтовариством з атомної енергії і їхніми державами-членами, з іншої сторони, ратифікована із заявою Законом від 16.09.2014 № 1678-VII. URL: https://zakon.rada.gov.ua/ laws/show/984_011 (дата звернення: 15.02.2020)

92 Бернська конвенція про охорону літературних і художніх творів (Паризький акт від 24 липня 1971 р., змінений 2 жовтня 1979 р.). URL: https://zakon.rada.gov.ua/laws/ show/995_051 (дата звернення: 15.02.2020). 
3 огляду на це, за традицією, право інтелектуальної власності СС прийнято поділяти на право промислової власності й авторське право ${ }^{93}$. Разом із тим цей розподіл закріплено у двох конвенціях: Паризькій конвенції про охорону промислової власності та Бернській конвенції про охорону літературних творів і творів мистецтва ${ }^{94}$.

Проведені дослідження дали змогу встановити, що еволюція права IB в Свропі має давню історію й бере свій початок ще 3 перших десятиліть XIV століття ${ }^{95}$. Водночас проведене дослідження сприяло усвідомленню того, що на сучасному етапі охорона права інтелектуальної власності ЄС має все ж таки риси єдиної сформованої системи ${ }^{96} .3$ іншого боку, уважаємо за необхідне зазначити, що виникає потреба в обгрунтуванні системності охорони права інтелектуальної власності за визначенням П.К. Анохіна - фахівця 3 теорії функціональних систем ${ }^{97}$. Дійсно, ця система покликана слідувати двом чітким векторним спрямуванням: 1) формування єдиної гармонізованої системи охорони прав інтелектуальної власності в межах самого $Є С$; 2) прагнення в ЄС стимулювати створення ефективних систем охорони права IB в третіх країнах і сприяти розвитку міжнародного співробітництва в цій сфері ${ }^{98}$ з урахуванням умов цифрової економіки, які суттєво впливають на розвиток нових технологій.

3 огляду на те що система права СС має дворівневу систему, що включає, по-перше, загальноєвропейські правові документи (директиви), а по-друге, національні правові документи, цілком закономірним $є$ те, що правова основа охорони права інтелектуальної власності СС складається з численних директив, регламентів, угод та інших нормативно-правових актів ${ }^{99}$. До того ж під час формування європейських

93 Скордамалья В. Право інтелектуальної власності ЄС : навчальний посібник. Київ : ІМВ КНУ імені Тараса Шевченка, 2004. С. 9.

94 Бернська конвенція про охорону літературних і художніх творів (Паризький акт від 24 липня 1971 р., змінений 2 жовтня 1979 р.). URL: https://zakon.rada.gov.ua/laws/ show/995_051 (дата звернення: 15.02.2020).

95 Бояр А.О. Єдина політика ЄС у сфері інтелектуальної власності: передумови, формування системи, проблеми і перспективи. Науковий вісник Волинського державного університету імені Лесі України. Серія «Економічні науки». 2006. № 1. С. 278.

96 Там само.

97 Анохин П.К. Принципиальные вопросы общей теории функциональных систем : монография. URL: https://goo.gl/hgbmvz (дата звернення: 15.02.2020).

98 Бошицький Ю.Л. Деякі питання кодифікації чинного законодавства України в сфері інтелектуальної власності в контекстні міжнародних стандартів. Часопис Київського університету права. 2017. № 3. С. 188.

99 Шабалін А.В. Деякі питання захисту права інтелектуальної власності в СС. Теорія і практика інтелектуальної власності. Захист прав інтелектуальної власності. Київ. 2019. № 6. C. 48. 
стандартів правової охорони авторських і суміжних прав від 1988 року виділяють чотири етапи розвитку, що зумовлені: 1988-1994 pp. - політичною ініціативою ЄС із запровадження програми гармонізації; 1995-2001 pp. - розвитком інформаційного суспільства й ухваленням Інтернет-договорів ВОІВ; 2008-2009 pр. - політикою з утворення економіки на основі знань; 2010-2018 рр. - політикою з утворення єдиного цифрового ринку $\mathrm{CC}^{100}$. Проаналізувавши наведені результати, маємо певні питання щодо чинників, відповідно до яких розвивалося авторське право й суміжні права в СС: політика з утворення економіки на основі знань чи політика з утворення єдиного цифрового ринку ЄС? На нашу думку, єдиний цифровий ринок має розвиватися в інформаційному суспільстві, заснованому на знанні.

Нагадаємо, що в другій частині статті акцентовано увагу на охороні об'єктів права інтелектуальної власності ІТ-компаній, зокрема на комп'ютерних програмах і базах даних на національному рівні. Оскільки з'ясовано, що правова охорона програм і баз даних у країнах ЄС здійснюється відповідно до спеціальних Директив, уважаємо за доцільне проаналізувати, як саме гарантується забезпечення охорони цих об'єктів. Зокрема, Директива 2009/24/ЕС щодо правової охорони комп'ютерних програм установлює виключні права й обов'язки користувача комп'ютерної програми, які не містяться в угоді про торговельні аспекти інтелектуальної власності ТРІПС або в Бернській конвенції101. При цьому Директива визнає комп’ютерні програми, що охороняються нормами Бернської конвенції, як «літературні твори» й указує, що нею не надаються будь-які права щодо охорони «інтерфейсу, ідей чи принципів функціонування комп'ютерної програми» (ст. 1 п. 2 Директиви) ${ }^{102}$. Останні, за загальним правилом ${ }^{103}, \epsilon$ предметом патентної охорони, яку опосередковано погоджено в Директиві в ст. $8^{104}$.

\footnotetext{
${ }^{100}$ Капіца Ю.М. Уніфікація і гармонізація законодавства 3 охорони прав інтелектуальної власності держав-членів ЄС та законодавства України : автореф. дис. ... докт. юрид. наук : 12.00.03. Київ, 2019. С. 6.

101 Бернська конвенція про охорону літературних і художніх творів (Паризький акт від 24 липня 1971 р., змінений 2 жовтня 1979 р.). URL: https://zakon.rada.gov.ua/laws/ show/995_051 (дата звернення: 15.02.2020).

102 Директива 2009/24/€C. URL: https://eur-lex.europa.eu/legal-content/EN/TXT/?qid=14908 81026820\&uri=CELEX:32009L0024 (дата звернення: 15.02.2020).

103 Чибисов Д.М. Патентование компьютерных программ по праву ВТО: проблемы правовой квалификации и правоприменительная практика. Таджикистанский ежегодник международного публичного и частного прав. 2016. № 4/30. С. 106.
}

104 Там само. 
Водночас подібні положення стосуються й бази даних, які впроваджено в Директиві 96/9/EC ${ }^{105}$. Проведені дослідження дали можливість установити, що правова охорона надається будь-якій базі даних незалежно від форми іiі створення ${ }^{106}$. При цьому варто зазначити, що правова охорона баз даних не поширюється на комп'ютерні програми, які забезпечують доступ до них і їх функціонування. Для значної кількості випадків передбачена можливість визнання як пер-

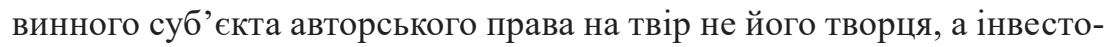
ра-виробника ${ }^{107}$. У зв'язку з цим варто зазначити, що в Україні існує дещо інший підхід, про який ішлося в другому розділі роботи.

Проведений аналіз дав змогу з'ясувати, що в багатьох країнах застосовується комплексний підхід до охорони комп'ютерних програм, який включає, окрім норм авторського права, ще й норми патентного права, договірне право, законодавство про недобросовісну конкуренцію, про комерційну таємницю тощо. До того ж установлено, що в деяких країнах ініційовані спроби створити спеціальну правову систему охорони комп'ютерних програм ${ }^{108}$.

Загалом наведені результати сприяли усвідомленню того, що нині практично всі розвинені країни активно використовують норми патентного права. Разом із тим установлено, що в частині країн СС реєстрація винаходів здійснюється лише після експертизи по суті, яка розглядає винахід на предмет відповідності критеріям охороноздатності. Унаслідок цього видача патенту суттєво ускладнюється через тривалу й досить дорогу процедуру, але власники отримують такий охоронний документ, який має значну економічну цінність і який третій стороні нелегко анулювати в судовому порядку ${ }^{109}$.

Установлено ${ }^{110}$, що інша група країн здійснює реєстрацію винаходів після простої формальної експертизи, видані патенти залишаються «слабкими» й можуть бути легко анульовані внаслідок

105 Директива СC 96/9/СС від 11.03.1996. База даних «Законодавство Украӥни». URL: https://zakon.rada.gov.ua/laws/card/994_241 (дата звернення: 13.02.2020).

106 Там само.

107 Еннан Р.Є. Правове регулювання відносин інтелектуальної власності у Європейському Союзі : автореф. дис. ... канд. юрид. наук : 12.00.03. Одеса, 2010. С. 11.

108 Потехіна В.О. Охорона інтелектуальної власності в умовах глобалізації : навчальний посібник. Київ : КУП НАНУ, 2009. С. 181.

109 Скордамалья В. Право інтелектуальної власності $\mathrm{CC}$ : навчальний посібник. Київ : IMВ КНУ імені Тараса Шевченка, 2004. С. 58.

110 Там само. 
судового позову ${ }^{111}$. Уважаємо за необхідне акцентувати увагу на тому, що ще із 70-х років у СС ведеться мова про створення єдиного патенту $\mathrm{EC}$, який би діяв на території всіх держав-членів Співтовариства ${ }^{112}$. Проте, як показали дослідження ${ }^{113}$, на сучасному етапі й досі спостерігаються певні невирішеності щодо запровадження єдиного патенту з одночасною дією на території всіх держав-членів ${ }^{114}$. Водночас у ЄС запроваджено єдину правову охорону промислових зразків на території $\mathrm{CC}^{115}$.

Отже, маємо підстави стверджувати, що система правової охорони права інтелектуальної власності в ЄС зазнає постійних удосконалень і доповнень. Водночас важливо, що ії ефективність дійсно стимулює розвиток безпечних ринкових відносин у Європі. Доречно підкреслити, що в такому аспекті було б доцільно впровадження єдиного підходу та, відповідно, наближення українського законодавства до законодавства СС у сфері IB ${ }^{116}$.

3 приводу цього вважаємо, що варто погодитися з Ю.М. Капіцею ${ }^{117}$, який обгрунтував пропозиції щодо впровадження в Україні сталого механізму наближення законодавства України у сфері IB до законодавства СС, а саме здійснення наближення законодавства у сфері IB з урахуванням вимог Закону України «Про Загальнодержавну програму адаптації законодавства України до законодавства $\mathrm{CC»}{ }^{118}$, що передбачає вищі стандарти наближення, ніж визначені Угодою про

111 Скордамалья В. Право інтелектуальної власності $\mathrm{CC}$ : навчальний посібник. Київ : IМВ КНУ імені Тараса Шевченка, 2004. С. 59.

112 Скордамалья В. Право інтелектуальної власності $\mathrm{CC}$ : навчальний посібник. Київ : IМВ КНУ імені Тараса Шевченка, 2004. С. 63.

113 Капіца Ю.М. Уніфікація і гармонізація законодавства з охорони прав інтелектуальної власності держав-членів ЄС та законодавства України : автореф. дис. ... докт. юрид. наук : 12.00.03. Київ, 2019. С. 6.

114 Там само.

115 Капіца Ю.М. Уніфікація і гармонізація законодавства з охорони прав інтелектуальної власності держав-членів ЄС та законодавства України : автореф. дис. ... докт. юрид. наук : 12.00.03. Київ, 2019. С. 7.

116 Капіца Ю.М. Уніфікація і гармонізація законодавства з охорони прав інтелектуальної власності держав-членів ЄС та законодавства України : автореф. дис. ... докт. юрид. наук : 12.00.03. Київ, 2019. С. 23.

117 Капіца Ю.М. Уніфікація і гармонізація законодавства з охорони прав інтелектуальної власності держав-членів ЄС та законодавства України : автореф. дис. ... докт. юрид. наук : 12.00.03. Київ, 2019. С. 33.

118 Про Загальнодержавну програму адаптації законодавства України до законодавства ЄC: Закон України від 18.03.2004 № 1629-IV. Дата оновлення: 04.11.2018. URL: https://zakon.rada.gov.ua/laws/show/1629-15 (дата звернення: 13.02.2020). 
асоціацію ${ }^{119}$. Водночас у роботі поділяється позиція щодо розроблення Концепції охорони авторського права і суміжних прав у цифровому середовищі ${ }^{120}$. До речі, у розділі II роботи спеціальна увага приділялася оцифровуванню об'єктів авторського права, наданню доступу до творів у цифровій формі, застосуванню цифрових ідентифікаторів тощо.

Уважаємо за важливе дослідити стан технологічної охорони права інтелектуальної власності в СС та інших країнах світу. Передусім варто зазначити, що в розділі 1 роботи з'ясовано, що саме технологія блокчейн $\epsilon$ тієї платформою, яка гарантує охорону права IB завдяки своїм функціональним характеристикам. Ураховуючи те що ще в 1991 році ідею технології блокчейн викладено в статті Хабера і Сторнетта ${ }^{121}$, цілком закономірно, що ця технологія постійно розвивалася й у США, і в країнах ЄС. Водночас, як показали дослідження О.О. Кудь ${ }^{122}$, у багатьох країнах світу одиницею обліку блокчейну є токен, який уважається спекулятивним активом. На нашу думку, унаслідок існування ризику швидкого знецінювання спекулятивних активів саме вони $є$ слабким ланцюжком під час упровадженні ідеї смарт-контрактів задля передачі майнових прав на об'єкти IB.

Що стосується охорони права IB шляхом оцифровування відповідних об'єктів IB (створення унікальних цифрових копій), то на базі технології блокчейн це, безумовно, можливо завдяки створенню цифрового активу, який має унікальний ідентифікатор та обертається в блокчейні. Тобто виникає потреба у використанні спеціальної методики діагностики токену на відповідність цифровому активу ${ }^{123}$. Уважаємо, що необхідно розуміння фахівців з технологічної охорони права IB в зарубіжних країнах, що запропонована українська методика робить цифровий актив зрозумілим для норм чинного законодавства в межах кожної конкретної юрисдикції та є основою для юридично

119 Капіца Ю.М. Уніфікація і гармонізація законодавства з охорони прав інтелектуальної власності держав-членів ЄС та законодавства України : автореф. дис. ... докт. юрид. наук : 12.00.03. Київ, 2019. С. 33.

120 Капіца Ю.М. Уніфікація і гармонізація законодавства 3 охорони прав інтелектуальної власності держав-членів ЄС та законодавства України : автореф. дис. ...докт. юрид. наук : 12.00.03. Київ, 2019. С. 34.

121 Кудь О.О., Кучерявенко М.П., Смичок С.М. Цифрові активи та їх економіко-правове регулювання : монографія. Харків : Право, 2019. С. 16.

122 Кудь О.О., Кучерявенко М.П., Смичок Є.М. Цифрові активи та їх економіко-правове регулювання : монографія. Харків : Право, 2019. С. 71.

123 Кудь О.О., Кучерявенко М.П., Смичок Є.М. Цифрові активи та їх економіко-правове регулювання : монографія. Харків : Право, 2019. С. 66-70. 
захищеної реалізації права власності на цифровий актив відповідно до всіх чинних міжнародних стандартів ${ }^{124}$.

Аналіз літератури ${ }^{125}$ дав змогу 3'ясувати, що сьогодні поняття «цифровий актив» у багатьох країнах на законодавчому рівні й досі не закріплено. Водночас більшість країн-членів СС виступають за врегулювання та впровадження блокчейну у правове поле. Варто зазначити, що нині в нормативно-правових актах багатьох країн світу спостерігається використання таких понять, як «криптовалюта», «віртуальна валюта» та «цифровий актив», зокрема правове регулювання цих об'єктів відображено в праві ЄС, а також у практиці Європейського суду з прав людини та Суду ЄС. Підсумовуючи, варто зазначити, що прогрес і перспективи цифрових активів вимагають реального правового врегулювання цих об' єктів із закріпленням основоположних понять, утворених у цій сфері.

Отже, проведені дослідження стану правотворчості країн $\mathrm{CC}$, а саме щодо охорони права IB в цих країнах в умовах цифрової економіки, дають змогу дійти висновку: а) правовий аспект цієї охорони $\epsilon$ вельми корисним для України, що вимагає конструктивного впровадження; б) водночас технологічна охорона права IB в цих країнах може впроваджувати окремі новації України.

\section{ВИСНОВКИ}

Отже, проведені дослідження дають змогу дійти резюмувати таке:

1. Обгрунтовано, що перевірку висунутої наукової гіпотези варто здійснювати на базі міждисциплінарних досліджень, а саме: загальної теорії права, інформаційного права, права інтелектуальної власності, загальної теорії функціональних систем, новітніх знань з інформаційних технологій, цифрової економіки.

2. Переконалися, що на правотворчість у сфері інтелектуальної власності здійснюють вплив: а) цифрова економіка та їі інструменти (блокчейн, цифровий актив, токен блокчейну, смарт-контракт), тобто економічний фактор; б) європейська інтеграція України, тобто політичний фактор.

3. Установлено, що завдяки одній із категорії технології блокчейн - цінності, а також потенціалу його природи щодо

${ }^{124}$ Кудь О.О., Кучерявенко М.П., Смичок Є.М. Цифрові активи та їх економіко-правове регулювання : монографія. Харків : Право, 2019. С. 71.

${ }^{125}$ Кудь О.О., Кучерявенко М.П., Смичок Є.М. Цифрові активи та їх економіко-правове регулювання : монографія. Харків : Право, 2019. С. 257. 
самостійного сприяння всебічному формуванню довірчих, прозорих, рівних відносин у суспільстві виникає реальна можливість охорони прав людини, зокрема права IB, а саме технологічної охорони. Переконалися, що ефективність застосування цієї технології у сфері IB може посилюватися завдяки своїм функціональним можливостям, зокрема щодо обліку як інформації, так і прав, поданих у вигляді інформаційного ресурсу, а також створення середовища обертання цих прав.

4. Дійшли висновку, що, з огляду на властивості цифрового активу, перспективним напрямом технологічної охорони права IB є реєстрація об' єктів цього права у вигляді інформаційного ресурсу, так зване оцифрування. 3'ясовано, що ще одним перспективним напрямом технологічної охорони права IB $є$ впровадження ідеї смарт-контрактів на базі розподіленого реєстру. Водночас установлено, що й під час упровадження ідеї смарт-контрактів на базі розподіленого реєстру, і під час вирішення проблеми ліквідації анонімності користувачів блокчейну виникає потреба в комплексному використанні інструментів цифрової економіки й правових засобів інформаційного права та права інтелектуальної власності.

5. Розкрито особливості правової охорони інтересів учасників суспільних відносин в ІТ-компаніях, інтелектуальними продуктами яких є передусім комп'ютерні програми й бази даних. Визначено підходи до правової охорони прав особистого та майнового характеру для фізичної та юридичної особи. З'ясовано підстави для охорони об'єктів творчої діяльності ІТ-компаній авторським чи патентним правом. Наведено характеристику патентів українських IT-компанії, які охороняють, наприклад, ідею цифрового активу.

6. Установлено особливості першої у світі угоди між українськими компаніями з купівлі-продажу токену блокчейну Bitbon як нематеріального активу. Водночас усвідомлено, що досягненню цієї мети сприятиме дослідження комплексних правовідносин (цивільно-інформаційних), тобто правових засобів як права інтелектуальної власності, так й інформаційного права.

7. Обгрунтовано, що впровадження високих стандартів охорони права IB фізичних і юридичних осіб на національному рівні сприятимуть наявні в зарубіжних країнах підходи до забезпечення правової охорони зазначеного права. Визначено пропозиції щодо наближення законодавства України у сфері інтелектуальної власності й інформаційного законодавства до відповідного законодавства ЄС. 
8. Поетапна перевірка висунутої наукової гіпотези дала змогу дійти висновку щодо іiї справедливості. Разом із тим задля досягнення поставленої мети пропонуємо формування відповідного механізму системного утворення, невід'ємними складниками якого є правова охорона (правові засобі права інтелектуальної власності й інформаційного права); технологічна охорона (інструменти цифрової економіки); європейські стандарти охорони права інтелектуальної власності. Між зазначеними складниками - зв'язки взаємосприяння. Існує потреба в подальшому опрацюванні наведеної пропозиції.

\section{АНОТАЦІЯ}

Стаття присвячена дослідженню впливу цифрової економіки та європейської інтеграції на правотворчість у сфері інтелектуальної власності в умовах розбудови інформаційного суспільства й інформаційного законодавства в Україні. Для досягнення мети висунуто наукову гіпотезу: необхідною умовою належного забезпечення права інтелектуальної власності в умовах розбудови суспільства знань в Україні $\epsilon$ комплексне використання правових засобів інформаційного права й права інтелектуальної власності, інструментів цифрової економіки (технологія блокчейн, токен блокчейн, цифровий актив, смарт-контракт) і відповідного досвіду Європейського Союзу. Обгрунтовано доцільність використання міждисциплінарного підходу для перевірки гіпотези. Установлено, що потенціал природи блокчейну та одна 3 його категорій - цінність - дають реальну можливість технологічної охорони права інтелектуальної власності. 3'ясовано перспективні напрями технологічної охорони: «оцифрування» зазначеного права; упровадження смарт-контрактів. Розкрито особливості правової охорони інтересів учасників суспільних відносин в ІТ-компаніях, інтелектуальними продуктами яких є комп'ютерні програми та бази даних. 3'ясовано підстави для охорони цих продуктів авторським чи патентним правом. Обгрунтовано потребу у взаємодії правових засобів права інтелектуальної власності й інформаційного права під час дослідження комплексних правовідносин задля належного виконання угод щодо розпорядження майновими правами на інтелектуальну власність. Установлено позитивні результати правової охорони права інтелектуальної власності в Свропейському Союзі. Визначено пропозиції щодо наближення законодавства України у сфері інтелектуальної власності та інформаційного законодавства до відповідного законодавства Європейського Союзу. Запропоновано системний механізм охорони 
права інтелектуальної власності в умовах розбудови інформаційного суспільства й інформаційного законодавства в Україні.

\section{ЛІТЕРАТУРА}

1. G20 Программа по развитию и сотрудничеству в сфере цифровой экономики (Итоговый документ 2016). URL: (дата звернення: 12.02.2020).

2. Про схвалення Концепції розвитку цифрової економіки та суспільства України на 2018-2020 роки та затвердження плану заходів щодо іiі реалізації: Розпорядження Кабінету Міністрів України від 17.01.2018 № 67-p. URL: https://www.kmu.gov.ua/npas/pro-shvalennyakoncepciyi-rozvitku-cifrovoyi-ekonomiki-ta-suspilstva-ukrayini-na20182020-roki-ta-zatverdzhennya-planu-zahodiv-shodo-yiyi-realizaciyi (дата звернення: 15.02.2020).

3. Яновицька Г.Б., Кучер В.О. Цивільне право України : підручник : у 2 т. / за ред. Г.Б. Яновицької. Львів : Новий Світ-2000, 2014. Т. 1. 444 с.

4. Угода про асоціацію між Україною, 3 однієї сторони, та Європейським Союзом, Європейським співтовариством 3 атомної енергії і їхніми державами-членами, 3 іншої сторони, ратифікована із заявою Законом від 16.09.2014 № 1678-VII. URL: https://zakon.rada.gov.ua/ laws/show/984_011 (дата звернення: 15.02.2020).

5. Арістова І.В. Наука «Інформаційне право» на новому етапі розвитку інформаційного суспільства. Правова інформатика. 2011. № 1. С. 3-11.

6. Про Рекомендації парламентських слухань на тему: «Законодавче забезпечення розвитку інформаційного суспільства в Україні» : Постанова Верховної Ради України від 03.07.2017 №1565-VII. Відомості Верховної Ради України. 2014. №33. Ст. 1163.

7. К обществам знаний : Всемирный доклад ЮНЕСКО. Париж : Изд-во ЮНЕСКО, 2005. 211 с.

8. Арістова І.В., Курило В.І., Калугін О.Ю. Впровадження інформаційнокомунікаційних технологій в аграрний сектор економіки України: організаційно-правовий аспект : монографія / за заг. ред. І.В. Арістової. Київ : Редакційно-видавничий центр НУБіП України, 2014. 193 с.

9. Бєляков К.І. Інформатизація в Україні: проблеми організаційногоправового та наукового забезпечення : монографія. Київ : КВІЦ, $2008.576 \mathrm{c}$.

10. Кудь О.О., Кучерявенко М.П., Смичок Є.М. Цифрові активи та їх економіко-правове регулювання : монографія. Харків : Право, 2019. 384 с.

11. Скакун О.Ф. Теорія держави і права (Енциклопедичний курс) : підручник. 2-е вид., перероб. і доп. Харків : Еспада, 2009. 752 с.

12. Что такое блокчейн простыми словами. URL: (дата звернення: 15.02.2020). 
13. Харитонов С.О., Харитонова О.І. IT-право: теорія та практика: навчальний посібник. 2-ге вид., доп. Одеса : Фенікс, 2019. 472 с.

14. Kud A.A. Substantiation of the term "digital asset": economic and legal aspects. International Journal of Education and Science. 2019. P. 1-20. DOI 10.26697/ijes.2019.1.06/

15. Бойко Н.О. Смарт контракти - чи справді договори та чи дійсно «розумні». URL: https://unba.org.ua/publications/3169-smart-kontrakti--chispravdi-dogovori-ta-chi-dijsno-rozumni.html (дата звернення: 15.02.2020).

16. Солодовников Н.В. Смарт-контракты: как они работают и зачем нужны. URL: https://www.pgplaw.ru/news/comments-in-the-media/smartcontracts-how-they-work-and-why-you-need (дата звернення: 15.02.2020).

17. Сергеев А.П. Право интеллектуальной собственности в Российской Федерации : учебник. Москва : Проспект, 1996. 704 с.

18. Цивільний кодекс України : Закон України від 16.01.2003 №№ 435-IV. Відомості Верховної Ради Украӥни. 2003. № 40-44. Ст. 356.

19. Баранова Л.М., Бєгова Т.І. Цивільне право : підручник : у 2 т. / за ред. В.І. Борисової, І.В. Спасибо-Фатєєвої, В.Л. Яроцького. Харків : Право. 2011. Т. $1.656 \mathrm{c}$.

20. Конституція України: Закон України від 28 червня 1996 р. № 254к/96-ВР / Верховна Рада України. Відомості Верховної Ради Украйни. 1996. № 30. Ст. 141.

21. Про авторське право і суміжні права: Закон України від 23.12.1993 № 3792-XII. URL: https://zakon.rada.gov.ua/laws/show/ 3792-12 (дата звернення: 15.02.2020).

22. Про охорону прав на винаходи і корисні моделі : Закон України від 15.12.1993 № 3687-XII. URL: https://zakon.rada.gov.ua/laws/card/368712 (дата звернення: 15.02.2020).

23. Бернська конвенція про охорону літературних і художніх творів (Паризький акт від 24 липня 1971 р., змінений 2 жовтня 1979 р.). URL: https://zakon.rada.gov.ua/laws/show/995_051 (дата звернення: 15.02.2020).

24. Жуванов Д.М., Стогній Є.С. Яку форму правової охорони обрати для комп'ютерної програми? URL: https://romanenko.biz/ua/publikatsii/41publications-copyright-ua/106-yaku-formu-pravovoji-okhoroni-obrati-dlyakomp-yuternoji-programi (дата звернення: 15.02.2020).

25. Коваль М.С. Права інтелектуальної власності на створений IT-продукт: проблемні моменти. URL: http:/uz.ligazakon.ua/ua/magazine article/EA009095 (дата звернення: 15.02.2020).

26. Офіційний сайт Українського інституту інтелектуальної власності. URL: https://ukrpatent.org/uk (дата звернення: 15.02.2020).

27. Офіційний сайт компанії Simcord. URL: https://www.simcord.com/ ua /legal-information-patents (дата звернення: 15.02.2020). 
28. Патент на винахід «Спосіб здійснення транзакції з передачі цифрової цінності (цифрового активу) та система передачі цифрових цінностей для його здійснення». Oфіиійний сайт компанії Simcord. URL: https://www.simcord.com/ua/legal-information-patents (дата звернення: 15.02.2020).

29. Система Bitbon. Офіційний сайт компанії Simcord. URL: https://www.simcord.com/ua/bitbon-system (дата звернення: 15.02.2020).

30. Перша у світі угода між українськими компаніями 3 купівліпродажу точену блокчейну Bitbon як нематеріального активу офіційний сайт компанії Simcord. URL: https://www.simcord.com/ua/news/first-buyand-sell-transaction-of-the-bitbon-blockchain-token-as-an-intangible-assetbetween-ukrainian-companies-in-the-world (дата звернення: 15.02.2020).

31. Арістова I.В. Теоретико-правові засади інформаційних правовідносин. Юридична відповідальність за правопорушення в інформаційній сфері та основи інформаційної деліктологї : колективна монографія. Київ : КВУЦ, 2019. С. 36-62.

32. Венгеров А.Б. Теория государства и права: учебник для юридических вузов. 3-е изд. Москва : Юриспруденция, 1999. 528 с.

33. Анохин П.К. Принципиальные вопросы общей теории функциональных систем : монография. URL: https:/goo.gl/hgbmvz (дата звернення: 15.02.2020).

34. Дмитриева Г.К. Цифровые финансовые активы: проблемы коллизионного регулирования. Актуальные проблемы российского права. 2019. № 5 (102). С. 120-128.

35. Капіца Ю.М. Уніфікація і гармонізація законодавства 3 охорони прав інтелектуальної власності держав-членів СС та законодавства України : автореф. дис. ... докт. юрид. наук : 12.00.03. Київ, 2019. 43 с.

36. Скордамалья В. Право інтелектуальної власності ЄС : навчальний посібник. Київ : ІМВ КНУ імені Тараса Шевченка, 2004. 156 с.

37. Бояр А.О. Сдина політика СС у сфері інтелектуальної власності: передумови, формування системи, проблеми і перспективи. Науковий вісник Волинського державного університету імені Лесі України. Серія «Економічні науки». 2006. № 1. С. 277-284.

38. Бошицький Ю.Л. Деякі питання кодифікації чинного законодавства України в сфері інтелектуальної власності в контекстні міжнародних стандартів. Часопис Київського університету права. 2017. № 3. C. $187-192$.

39. Шабалін А.В. Деякі питання захисту права інтелектуальної власності в СС. Теорія і практика інтелектуальної власності. Захист прав інтелектуальної власності. Київ, 2019. № 6. С. 46-54. 
40. Директива 2009/24/EC. URL: https://eur-lex.europa.eu/legal-content/ EN/TXT/? qid=1490881026820\&uri=CELEX:32009L0024 (дата звернення: 15.02.2020).

41. Чибисов Д.М. Патентование компьютерных программ по праву BTO: проблемы правовой квалификации и правоприменительная практика. Таджикистанский ежегодник международного публичного и частного прав. 2016. № 4/30. С. 104-113.

42. Директива СС 96/9/СС від 11.03.1996 р. База даних «Законодавство Украӥни». URL: https://zakon.rada.gov.ua/laws/card/994_241 (дата звернення: 15.02.2020).

43. Еннан Р.С. Правове регулювання відносин інтелектуальної власності у Європейському Союзі : автореф. дис. ... канд. юрид. наук : 12.00.03. Одеса, 2010. 22 с.

44. Потехіна В.О. Охорона інтелектуальної власності в умовах глобалізації : навчальний посібник. Київ : КУП НАНУ, 2009. 354 с.

45. Про Загальнодержавну програму адаптації законодавства України до законодавства ЄC: Закон України від 18.03.2004 № 1629-IV. URL: https://zakon.rada.gov.ua/laws/show/1629-15 (дата звернення: 15.02.2020).

\section{Information about authors:}

Aristova I. V.,

Doctor of Law, Professor, Head of the Department of Administrative and Information Law Sumy National Agrarian University 160, Herasym Kondratiev Street, Sumy, Ukraine

Karpik Yu. A., Student of Master's degree of Law Sumy National Agrarian University 160, Herasym Kondratiev Street, Sumy, Ukraine DOI https://doi.org/10.30525/978-9934-588-43-3/1.16 